\title{
Validasi Modul “MISI” untuk Meningkatkan Pengetahuan dan Keterampilan Komunikasi Kesehatan Reproduksi pada Remaja
}

\section{Validation of "MISI" to Improve the Knowledge and Communication Skills about Adolescent Reproductive Health}

\author{
Maria Goretti Keshia Sawitri ${ }^{1}$, Ira Paramastri ${ }^{2}$ \\ 1,2Fakultas Psikologi, Universitas Gadjah Mada
}

\begin{abstract}
The increasing number of adolescents risk behaviors and its impacts are concerning. Those behaviors and conditions cause physical and psychological effects. Because adolescence is one of the most critical phase in the lifespan, parents are expected to be their primary support system and one of the most important resources to deliver the knowledge. Yet, there are many parents who do not give their children sexual education. Some of parents lack the knowledge while others feel ashamed and do not communicate openly with their children. The "MISI" module was designed to improve parental knowledge and communication skills on delivering sexual education to their adolescent children $(9-15$ years old). The research used one group pretest-posttest design. The participants of this research consisted of 8 individuals. The pretest and posttest data was analyzed using Wilcoxon Sign-rank Test and descriptive data. The result showed that there was significant difference both on knowledge score (with $\mathrm{z}=-2.536$ and $\mathrm{p}$-value $=0.011(\mathrm{p}<0.05)$ and communication skills score $(\mathrm{z}=-2.541$ and $\mathrm{p}$-value $=$ $0.012(\mathrm{p}<0.05))$. Based on these results, MISI module can improve parental knowledge and communication skills on delivering sexual education to their adolescent children.
\end{abstract}

Keywords: adolescents, communication, parents, sexual education, validation

Abstrak. Banyaknya kasus perilaku seksual berisiko dan dampaknya pada remaja menimbulkan perhatian. Dampak dari hal tersebut bermacam-macam, mulai dari dampak fisik hingga psikologis. Fase remaja merupakan fase yang krusial untuk menuju dewasa. Orang tua diharapkan dapat menjadi figur pendamping utama untuk dapat menyampaikan pendidikan kesehatan reproduksi dan seksual. Meski demikian, orang tua kerap tidak memberikan informasi mengenai hal tersebut. Penyebabnya karena kurangnya pengetahuan, menganggap hal itu tabu, hingga komunikasi yang tidak terbuka dengan anak. Modul "MISI" bertujuan untuk meningkatkan pengetahuan dan keterampilan komunikasi orang tua dalam menyampaikan topik tersebut pada anak mereka yang beranjak remaja, berusia 9 sampai 15 tahun. Penelitian ini dilaksanakan dengan metode one group pretest-posttest design kepada delapan partisipan. Data hasil variabel pengetahuan dan keterampilan dianalisis menggunakan Wilcoxon Signrank Test dan data deskriptif. Hasil pengujian menunjukkan menunjukkan variabel pengetahuan memiliki nilai $z=-2,536$ sedangkan $p$-value sebesar $0,011(p<0,05)$, sedangkan keterampilan komunikasi memiliki nilai $z=-2,541$ dan $p$-value sebesar 0,012 $(p<0,05)$. Hasil tersebut menunjukkan bahwa modul MISI secara signifikan dapat meningkatkan pengetahuan dan keterampilan komunikasi orang tua dalam menyampaikan materi kesehatan reproduksi pada anak.

Kata kunci: kesehatan reproduksi; komunikasi; orang tua; remaja; validasi 
Masa remaja merupakan periode peralihan yang dapat menyebabkan berbagai macam tekanan. Hal tersebut dipengaruhi oleh banyaknya perubahan, antara lain perkembangan otak, perubahan fisik, munculnya keinginan untuk mandiri, serta perubahan pola interaksi sosial (Casey, Getz, \& Salvan, 2008). Tekanan tersebut dapat menimbulkan kerentanan munculnya perilaku berisiko, seperti penyalahgunaan obat terlarang, konsumsi alkohol, perundungan, hingga masalah yang berkaitan dengan perilaku seksual (Kipping et al., 2012; Santrock, 2007).

Perilaku seksual berisiko tersebut di antaranya memiliki dampak seperti kehamilan tidak diinginkan yang berefek jangka panjang pada remaja. Selain dampak komplikasi fisik dan kematian, kehamilan pada remaja memiliki risiko berupa stigma dan diskriminasi, kesulitan finansial, putus sekolah, hingga permasalahan psikologi seperti stress, rendahnya efikasi diri, dan depresi (Corcoran, 2016).

Selain kehamilan, infeksi menular seksual (IMS) dan HIV/AIDS pada remaja juga patut diperhatikan. Secara global, WHO mencatat bahwa satu dari dua puluh pemuda berusia 20 - 24 tahun, yang disusul dengan remaja 15 - 19 tahun mengalami IMS setiap tahunnya. Dalam kasus HIV, terdapat perkiraan 2,1 juta remaja di seluruh dunia yang terjangkit (WHO, 2012). Di Indonesia, Departemen Kesehatan Republik Indonesia (2013) mencatat 140.803 kasus IMS sepanjang tahun 2012, sedangkan kasus HIV/AIDS pada remaja usia 15 - 19 tahun mencapai 3,1\%.

Baik IMS maupun HIV/AIDS dapat memberikan berbagai macam dampak bagi kehidupan remaja yang mengalaminya. Selain menimbulkan risiko kesehatan seperti ketidaksuburan hingga kematian, mereka juga menerima stigma masyarakat, mengalami rasa malu, self-esteem yang rendah, depresi, kecemasan, gangguan perilaku, hingga tidak mampu menghadapi masalah sehari-hari (Vreeman et al., 2017).

Selain kedua hal di atas, pelecehan dan kekerasan seksual pada remaja merupakan hal yang patut diwaspadai. Pelaku justru biasanya datang dari orang terdekat korban (Foshee et al., 2004). Pemerkosaan dalam hubungan asmara (date rape), maraknya perkenalan lewat media sosial, adanya kekerasan lain terkait relasi kuasa (perundungan, hubungan di sekolah, kekerasan dalam rumah tangga), merupakan faktor-faktor risiko terjadinya kekerasan seksual pada remaja (Dowdell et al., 2011; Vivolo et al., 2010).

Kekerasan seksual terhadap remaja memiliki dampak bermacam-macam dan jangka panjang. Beberapa akibat dari kekerasan seksual pada remaja antara lain gejala Post Traumatic Stress Disorder (PTSD), depresi, kecenderungan bunuh diri, konsumsi alkohol dan penyalahgunaan obat terlarang, hingga kembali menjadi korban di saat dewasa atau bahkan menjadi pelaku dan melakukan perilaku seksual berisiko (Kaufman, 2008). Terdapat pula beberapa kasus ketika korban menekan memorinya sehingga tidak mengingat kekerasan tersebut hingga dewasa, tetapi mengganggu proses dalam kehidupannya (Romero et al., 2018).

Selain itu, temuan lain menyebutkan, salah satu risiko yang muncul jika remaja mengakses internet tanpa perlindungan dan pengawasan orang tua di antaranya adalah kekerasan seksual (biasanya setelah janji bertemu dan adanya unsur penipuan), menyerap 
dan mempraktikkan hal-hal seksual dalam dunia nyata pada sasaran yang tidak seharusnya (teman, pasangan, anak yang lebih muda) dan memperbesar risiko remaja menjadi pelaku kekerasan, selain mendapatkan informasi-informasi serta akses terkait pengetahuan reproduksi dan seksual yang tidak selalu akurat (Rosyidah \& Nurdin, 2018; Yullidya, 2015).

Kejadian-kejadian di atas dapat dicegah dan dikendalikan dengan beberapa upaya, salah satunya adalah dengan program pendidikan kesehatan reproduksi. Menurut beberapa penelitian, pendidikan kesehatan reproduksi terbukti dapat mengurangi angka kehamilan tidak diinginkan (KTD) maupun mencegah perilaku seksual berisiko pada remaja, seperti melakukan hubungan seksual pranikah yang bebas atau risiko kekerasan seksual (Kirby, 2008; Kohler et al., 2008; Lindberg et al., 2012; Mueller et al., 2008). Dari hasil tersebut, dapat dikatakan bahwa pendidikan reproduksi mampu memberikan kendali bagi remaja dalam berperilaku (Bearinger et al, 2007).

Meski telah ada beberapa pendekatan baik di sekolah maupun komunitas, masih ada beberapa catatan dalam pelaksanaan program-program pendidikan kesehatan reproduksi. Seringkali, pendidikan kesehatan reproduksi bukan menjadi materi yang utama, sedangkan di puskesmas masih terjadi penolakan dari beberapa sekolah terkait materi kesehatan reproduksi karena benturan nilai. Oleh karena itu, pemberian materi kesehatan reproduksi kepada remaja sesungguhnya tidak harus melalui media formal, tetapi juga bisa melalui jalan informal.

Pemberian informasi secara informal dapat dilakukan melalui teman sebaya maupun sosok yang menjadi model atau panutan, seperti guru dan orang tua (Pop \& Rusu, 2015). Penelitian terdahulu mengenai peningkatan efikasi diri diberikan pada guru untuk menyampaikan pengetahuan kesehatan reproduksi dan seksualitas terhadap remaja melalui modul Panda menunjukkan pentingnya peran guru sebagai salah satu model utama bagi remaja secara institusional (Hapsari, 2018). Penelitian serupa sebelumnya yang menghasilkan modul pelatihan kesehatan reproduksi dan pencegahan kekerasan seksual seperti Jari Peri (Islawati \& Paramastri, 2015) dan Kenari Duri (Solenta, 2019) juga menyasar guru di institusi pendidikan. Di luar ranah institusi resmi, orang tua menjadi agen utama dalam menyampaikan pengetahuan tersebut.

Remaja masih dalam usia di bawah perwalian orang tua. Sebagai salah satu orang terdekat, orang tua diharapkan mampu mengomunikasikan pendidikan kesehatan reproduksi tersebut. Dengan orang tua sebagai agen informasi, ada beberapa manfaat, di antaranya hal tersebut terbukti efektif dalam mencegah terjadinya kekerasan seksual, mengurangi perilaku seksual berisiko, melatih pemahaman orang tua dan anaknya, dan menjalin komunikasi yang baik (Wooden \& Anderson, 2012). Hubungan yang baik dan saling percaya antar orang tua dan anak remajanya dapat meningkatkan strategi coping anak sehingga ia akan dapat memiliki kemampuan pengambilan keputusan yang lebih sehat, termasuk berkaitan dengan kesehatan reproduksi dan seksualitasnya (Lezin et al., 2004).

Meski demikian, komunikasi antara orang tua dan remaja tidak selalu berjalan lancar. Hal ini disebabkan adanya keinginan remaja melepaskan diri dari orang tua dan lebih banyak bersama dengan teman sebaya atau disebut dengan dezatelisation (Santrock, 2007). 
Dalam penyampaian materi pendidikan kesehatan reproduksi, orang tua seringkali juga merasa tidak yakin akan kemampuan dan pengetahuannya dalam hal tersebut (Walker et al., 2008). Orang tua dengan pengetahuan yang cukup memadai pun sering memiliki kebingungan dalam menyampaikan materi kesehatan reproduksi, karena hal tersebut berkaitan dengan nilai-nilai budaya atau agama yang memungkinkan hal ini dianggap tabu. Selain itu, saat ini perkembangan teknologi telah cukup pesat dan menimbulkan kesenjangan pemahaman, komunikasi serta kontrol orang tua terhadap anak (Moawad \& Ebrahem, 2016). Hal ini juga dapat menjadi faktor penghambat komunikasi orang tua mengenai pendidikan kesehatan reproduksi.

Oleh karena itu, orang tua perlu diberikan fasilitas untuk dapat mengembangkan pengetahuan dan keterampilan komunikasi kepada anaknya yang beranjak remaja mengenai kesehatan reproduksi. Peneliti mengembangkan modul yang Pijar (Burrahma, 2018) dengan penambahan materi mengenai pentingnya pemahaman teknologi informasi dan penekanan pada pencegahan kekerasan seksual.

Dalam penelitian ini, proses penyampaian informasi atau komunikasi dilakukan baik dengan melibatkan kata-kata (verbal) maupun komponen non-verbal seperti kontak mata, ekspresi, dan intonasi suara juga penting (DeVito, 2014). Lebih lanjut, untuk diperlukan strategi komunikasi efektif yang mengacu pada McKay et al. (2009) yang meliputi (a) mendengarkan aktif, (b) mengekspresikan diri, (c) dan mencari solusi bersama.

Materi kesehatan reproduksi dan seksual yang diberikan yaitu mengenai kesehatan reproduksi yang mengacu pada American Psychological Association atau APA (2005) yang lebih komprehensif dalam menyertakan faktor psikologis dan sosial. Adapun materi mengenai pentingnya kendali teknologi informasi dan pencegahan kekerasan seksual akan ditambahkan berdasarkan pendekatan dari Center for Disease Control and Prevention (CDC) (David-Ferdon, 2014), yaitu melalui promosi perlindungan terhadap kerentanan, mengajari keahlian untuk pencegahan kekerasan seksual, menciptakan kesempatan untuk berdaya, menciptakan lingkungan yang aman, dan menyediakan dukungan bagi penyintas.

Pemberian materi ini akan diberikan dengan menggunakan prinsip observational learning dari Bandura (1988), yaitu dengan meletakkan fasilitator dan observer sebagai model bagi orang tua. Selain memberikan materi pengetahuan, fasilitator, dibantu dengan observer juga akan memberikan contoh keterampilan yang akan diikuti oleh peserta melalui sesi roleplay. Seusai dari pelatihan, diharapkan apa yang telah dipelajari tadi dapat diterapkan kepada anak remaja para peserta di rumah. Proses tersebut dilakukan dengan menjalani empat tahap observational learning, yaitu atensi, retensi, reproduksi, dan motivasi (Bandura, 1988). Berdasarkan keterangan di atas, modul kemudian disusun.

Modul "MISI" (PahaMI dan KomunikaSIkan) bertujuan untuk memberikan informasi mengenai pengetahuan pendidikan kesehatan reproduksi dan seksual (PKRS) remaja dan keterampilan komunikasi dalam menyampaikan hal tersebut dari orang tua kepada anak mereka. Modul ini merupakan pengembangan dari modul "PIJAR" (Pahami dan Ajarkan) yang sebelumnya disusun oleh Burrahma (2018). 
Penelitian ini bertujuan untuk menguji apakah modul "MISI" dapat meningkatkan pengetahuan dan keterampilan komunikasi orang tua untuk menyampaikan materi kesehatan reproduksi pada remaja.

\section{Metode}

Variabel terikat dari penelitian ini adalah pengetahuan kesehatan reproduksi dan seksual dan keterampilan komunikasi efektif orang tua, sedangkan variabel bebas penelitian ini adalah modul MISI. Pengujian modul ini dilakukan melalui dua tahap validasi, yaitu validasi isi modul dan validasi empirik berupa ujicoba modul.

Validasi isi modul dilakukan dengan memberikan Lembar Rating Relevansi kepada empat pakar atau yang disebut dengan expert judgment. Pakar memberikan rating 1 (Sangat Tidak Sesuai) hingga 5 (Sangat Sesuai) mengenai modul MISI pada lembar penilaian tersebut dan memberikan saran secara tertulis. Dari hasil tersebut, skor yang diperoleh dihitung menggunakan perhitungan Aiken's $\mathrm{V}$ dan modul diperbaiki sesuai saran dari pakar.

Setelah validasi isi dilakukan, validasi empirik dilakukan dengan ujicoba pelaksanaan pelatihan menggunakan modul MISI. Pelatihan modul MISI dilaksanakan sebanyak dua pertemuan di sebuah RW di Yogyakarta. Partisipan yang dipilih adalah yang memenuhi kriteria: (a) orang tua dengan anak remaja awal berusia 9 - 15 tahun, (b) pendidikan minimal SMA, (c) berdomisili di Yogyakarta, dan (d) belum pernah mengikuti pelatihan kesehatan reproduksi dan seksual sebelumnya. RW ini memiliki demografi yang cukup rentan dalam permasalahan perilaku berisiko, tetapi memiliki komitmen dan kepedulian yang masih rendah untuk menghadiri acara psikoedukasi terkait atau acara lain. Warga yang sekiranya memenuhi kriteria diundang dalam sosialisasi. Oleh karena itu, response rate dari hasil sosialisasi tersebut didapatkan delapan partisipan yang bersedia dan memenuhi kriteria. Setelah bersedia, partisipan diberikan informed consent untuk diisi dan ditandatangani. Pelatihan dilaksanakan di balai RT dari RW tersebut dan berlangsung selama 180 menit di hari pertama dan 210 menit di hari kedua. Modul MISI yang digunakan berisi enam sesi, dengan empat sesi di hari pertama (Keterampilan Komunikasi, Tumbuh Kembang Remaja, dan Psikoseksual Remaja) dan tiga sesi di hari kedua (Perilaku Berisiko dan Dampaknya, Teknologi Informasi dan PKRS, serta Kekerasan Seksual).

Alat ukur yang digunakan untuk pengambilan data yaitu Skala Pengetahuan Kesehatan Reproduksi dan Seksual yang diadaptasi dari penelitian terdahulu oleh Burrahma (2018) yang diisi oleh partisipan pada pretest dan post-test. Skala ini memiliki reliabilitas 0,88 dengan indeks daya beda aitem bergerak antara 0,3-0,75. Dengan kata lain, skala ini telah terbukti dapat digunakan untuk mengukur pengetahuan kesehatan reproduksi pada orang tua.

Selain itu, untuk mengukur keterampilan komunikasi, observer mengobservasi pretest dan posttest bermain peran menggunakan Lembar Observasi Keterampilan Komunikasi yang juga diadaptasi dari Burrahma (2018). Instrumen tambahan lain yang digunakan yaitu 
Lembar Observasi per Sesi, Lembar Kerja, dan Lembar Evaluasi yang diisi oleh partisipan. Hal ini dilakukan untuk mengecek apakah partisipan memahami manipulasi yang diberikan, sehingga terjadi internalisasi. Lembar Kerja berisi kegiatan, diskusi, atau pertanyaan partisipan, sedangkan Lembar Evaluasi merangkum pemahaman partisipan atas materi, cara penyampaian, hingga fasilitas dari peneliti dan fasilitator.

Desain penelitian ini menggunakan metode statistik non parametrik One Group Pretest Posttest Design. Data penelitian ini diuji dengan membandingkan perubahan sebelum dan setelah perlakuan pada satu kelompok, sehingga dilakukan analisis within subject. Pengukuran perbedaan pengetahuan kesehatan reproduksi dan seksual maupun keterampilan komunikasi dilakukan pada saat pretest dan post-test. Analisis data yang diperoleh diuji menggunakan Wilcoxon Sign-rank Test yang biasa digunakan untuk mengukur data dengan distribusi tidak normal (Azwar, 2014). Perubahan pengetahuan dan keterampilan komunikasi dalam bentuk deskriptif mengenai masing-masing partisipan ditambahkan dari hasil catatan tambahan lembar observasi keterampilan komunikasi.

\section{Hasil}

Hasil pengujian validitas isi modul MISI bergerak antara rentang 0,625 - 1,00. Hal ini menunjukkan bahwa validitas isi modul MISI dapat dikatakan baik. Rentang di atas 0,5 sudah dapat dikatakan validitasnya baik (Azwar, 2015). Angka terendah yaitu 0,625 berasal dari indikator cover modul pada aspek Tampilan, sehingga pada item tersebut cover diganti sesuai dengan saran dari ahli agar lebih menarik dan sesuai dengan isi modul. Kesesuaian materi atau isi modul dengan tujuan disampaikannya modul yaitu peningkatan pengetahuan dan keterampilan komunikasi orang tua bergerak antara 0,75-1,00. Dari hasil tersebut, dapat dikatakan bahwa modul MISI telah dianggap relevan untuk dapat dipraktikkan pada pelatihan yang melibatkan partisipan karena telah sesuai dengan tujuan disusunnya modul tersebut. Perbaikan modul yang dapat dilihat dalam tabel 1. 
Tabel 1.

Perbaikan Modul Setelah Validasi Isi

\begin{tabular}{|c|c|c|c|}
\hline No & Saran & Sebelum Validasi Isi & Sesudah Validasi Isi \\
\hline 1 & $\begin{array}{l}\text { Mengganti cover modul } \\
\text { dengan cover yang lebih } \\
\text { menarik }\end{array}$ & $\begin{array}{l}\text { Cover kurang menarik } \\
\text { dan } \\
\text { mencerminkan suasang } \\
\text { kehangatan orang tua } \\
\text { dan anak }\end{array}$ & $\begin{array}{llr}\text { Cover diganti } & \text { sesuai } \\
\text { dengan } & \text { saran ahli } & \text { yang } \\
\text { lebih berwarna } & \text { dan } \\
\text { menggambarkan } & \text { isi } \\
\text { modul } & \end{array}$ \\
\hline 2 & $\begin{array}{l}\text { Tambahan ice breaking di sela } \\
\text { sesi dikarenakan panjangnya } \\
\text { jam pelatihan untuk menjaga } \\
\text { antusiasme dan konsentrasi } \\
\text { partisipan }\end{array}$ & $\begin{array}{l}\text { Ice breaking hanya ada di } \\
\text { Sesi Pembukaan }\end{array}$ & $\begin{array}{l}\text { Ice breaking yang } \\
\text { melibatkan gerakan fisik } \\
\text { ditambahkan sebelum sesi } \\
\text { Perkembangan Teknologi } \\
\text { dan PKRS }\end{array}$ \\
\hline 3 & $\begin{array}{l}\text { Perbaikan contoh dialog dan } \\
\text { penambahan tema roleplay di } \\
\text { sesi yang menggunakan } \\
\text { roleplay supaya partisipan } \\
\text { lebih memahami bentuk } \\
\text { keterampilan komunikasi yang } \\
\text { diharapkan }\end{array}$ & $\begin{array}{l}\text { Contoh dialog di Sesi } \\
\text { Komunikasi Efektif } \\
\text { masih meloncat, serta } \\
\text { pada sesi lainnya belum } \\
\text { diberikan tema atau } \\
\text { panduan roleplay }\end{array}$ & $\begin{array}{l}\text { Perbaikan contoh dialog } \\
\text { yang lebih realistis, } \\
\text { komunikatif, dan empatik } \\
\text { pada Sesi Komunikasi } \\
\text { Efektif dan adanya } \\
\text { tambahan panduan dan } \\
\text { tema pada sesi yang } \\
\text { mengandung roleplay }\end{array}$ \\
\hline 4 & $\begin{array}{l}\text { Pergantian gambar organ } \\
\text { reproduksi agar lebih mudah } \\
\text { dipahami orang tua }\end{array}$ & $\begin{array}{l}\text { Gambar } \quad \text { organ } \\
\text { reproduksi yang dipilih } \\
\text { terlalu rumit dan tidak } \\
\text { tampak depan }\end{array}$ & $\begin{array}{l}\text { Pergantian dengan } \\
\text { gambar yang lebih mudah } \\
\text { dipahami, jelas, dan } \\
\text { tampak depan }\end{array}$ \\
\hline 5 & $\begin{array}{l}\text { Penambahan manfaat positif } \\
\text { internet dan situs atau aplikasi } \\
\text { yang berguna pada sesi } \\
\text { Perkembangan Teknologi } \\
\text { sehingga tidak hanya melihat } \\
\text { segi negatif teknologi } \\
\text { informasi dan menimbulkan } \\
\text { ketakutan orang tua }\end{array}$ & $\begin{array}{l}\text { Belum ada manfaat } \\
\text { positif serta saluran atau } \\
\text { situs yang bisa diakses } \\
\text { oleh remaja sehingga } \\
\text { kebanyakan hanya } \\
\text { menimbulkan sisi } \\
\text { negatif teknologi }\end{array}$ & $\begin{array}{l}\text { Penambahan manfaat } \\
\text { internet bagi remaja serta } \\
\text { informasi mengenai } \\
\text { saluran atau situs yang } \\
\text { bermanfaat bagi mereka }\end{array}$ \\
\hline 6 & $\begin{array}{l}\text { Perbaikan alokasi waktu dan } \\
\text { pembagian sesi di hari } \\
\text { pertama dan kedua, serta } \\
\text { penjembatan atau review antar } \\
\text { materi }\end{array}$ & $\begin{array}{l}\text { Belum ada pembagian } \\
\text { alokasi waktu dan sesi } \\
\text { berdasar hari, serta } \\
\text { review rela } \\
\text { sebelumnya }\end{array}$ & $\begin{array}{l}\text { Baik pada matriks } \\
\text { maupun detail kegiatan } \\
\text { modul, ditambahkan } \\
\text { perbedaan sesi hari I dan } \\
\text { II, serta review materi } \\
\text { sebelumnya }\end{array}$ \\
\hline
\end{tabular}

Pada pengujian validitas empirik, data demografi partisipan terlihat dalam tabel 2 berikut ini. 
Tabel 2.

Data Demografik Partisipan

\begin{tabular}{lllcl}
\hline No & Nama (Inisial) & Usia & Pendidikan Terakhir & Usia Anak \\
\hline 1 & RY & 36 tahun & SMK & 9 tahun \\
2 & LNH & 27 tahun & SMA & 9 tahun \\
3 & EEVT & 35 tahun & S1 & 9 tahun \\
4 & FKR & 49 tahun & SMA & 12 tahun \\
5 & EWW & 46 tahun & SMA & 9 tahun \\
6 & T & 51 tahun & SMA & 15 tahun \\
7 & ES & 34 tahun & SMA & 9 \& 15 tahun \\
8 & K & 46 tahun & SMA & 15 tahun \\
\hline
\end{tabular}

Hasil pretest dan posttest menunjukkan adanya peningkatan gainscore baik dari Skala Pengetahuan Kesehatan Reproduksi dan Seksual maupun Lembar Observasi Keterampilan Komunikasi.

Mean dari pretest pengetahuan kesehatan reproduksi adalah 20 dengan hasil post-test menunjukkan skor 23,625 (gainscore $=3,625$ ), sedangkan mean dari lembar observasi keterampilan komunikasi menunjukkan skor 33 pada pretest dan 57,125 pada post-test (gainscore $=24,125$ ). Dari hasil tersebut menunjukkan bahwa ditinjau dari gainscore ada peningkatan setelah perlakuan dengan modul MISI.

Selanjutnya, analisis uji hipotesis skor partisipan dari pretest ke post-test dilakukan dengan analisis statistik non parametrik berupa Wilcoxon Sign-rank Test. Analisis ini dapat digunakan untuk mengukur perubahan skor pada partisipan yang sama.

Dari analisis tersebut, terdapat nilai $\mathrm{z}=-2,536$ sedangkan $p$-value sebesar 0,011 . Dengan signifikansi $p<0,05$, dapat dikatakan bahwa ada perbedaan signifikan mengenai pengetahuan kesehatan reproduksi partisipan pada sebelum dan sesudah perlakuan atau program MISI.

Dari hasil di atas, karena adanya perbedaan yang signifikan, dapat dikatakan bahwa hipotesis bahwa modul MISI dapat meningkatkan pengetahuan kesehatan reproduksi dan seksual dapat diterima.

Selain pengukuran signifikansi di atas, dilakukan pula pengukuran pengaruh perlakuan atau effect size. Hal ini dilakukan untuk melihat seberapa besar pengaruh modul MISI terhadap pengetahuan tersebut. Pengukuran effect size dilakukan dengan membagi nilai $\mathrm{Z}$ dengan akar jumlah partisipan (Field, 2009). Hasil pengukuran effect size tersebut yaitu sebesar 0,89 atau pengaruh sebesar $89 \%$ yang menandakan bahwa program MISI memiliki efek atau pengaruh yang besar terhadap perubahan pengetahuan partisipan mengenai kesehatan reproduksi dan seksual. Menurut Cohen (1998), pengaruh yang lebih dari 0,5 sudah merupakan pengaruh yang besar. 
Selanjutnya, hasil Wilcoxon Sign-rank Test pada tabel 3 di bawah ini mengenai variabel keterampilan komunikasi menunjukkan hasil nilai $Z=-2,524$ dan $p$-value $=0,012(p<0,05)$. Dari hasil tersebut, dapat dikatakan bahwa perubahan yang terjadi merupakan perubahan keterampilan komunikasi yang signifikan. Dengan demikian, hipotesis bahwa modul MISI dapat meningkatkan keterampilan komunikasi dapat diterima.

Hasil pengukuran effect size dari modul MISI terhadap keterampilan komunikasi juga menunjukkan angka sebesar 0,89 atau pengaruh sebesar $89 \%$ yang menandakan bahwa program MISI memiliki efek atau pengaruh yang besar terhadap perubahan keterampilan komunikasi partisipan untuk menyampaikan kesehatan reproduksi dan seksual pada anak.

Hasil evaluasi program MISI berkisar antara 75\% hingga 95\%, dengan aspek sejauh mana dapat dipraktikkan yang masih cenderung dirasa kurang membuat partisipan yakin, hingga pemahaman dan media yang digunakan yang telah mencapai angka 95\%. Ketercapaian program dianggap mencapai persentase $83 \%$, sehingga dapat dikatakan menunjukkan partisipan melihat program telah sesuai dengan tujuan awalnya.

Dari hasil evaluasi observer mengenai jalannya program per sesi, secara keseluruhan sesi dijalankan dengan baik dengan alokasi waktu yang cukup. Partisipan cenderung memperhatikan fasilitator, materi permainan berjalan dengan baik, begitu juga dengan materi yang melibatkan media seperti video. Beberapa partisipan terlibat aktif dalam diskusi, meski pada beberapa sesi yang penjelasannya panjang, terdapat partisipan yang kurang memperhatikan atau mengantuk. Terdapat pula partisipan yang senang untuk bercerita dan berdiskusi dengan fasilitator dan observer. Observer juga menilai bahwa fasilitator telah dapat menyampaikan materi dengan baik, begitu juga materi sesuai dengan tujuan yang dibutuhkan.

\section{Diskusi}

Hasil analisis pretest dan post-test mengenai pengetahuan PKRS memperlihatkan adanya kenaikan yang cukup signifikan. Hal ini menunjukkan, meski mengalami kenaikan yang ketika diukur masih cukup signifikan, perubahan kenaikan skor partisipan tidaklah banyak. Perubahan paling baik terjadi pada partisipan EEVT dan RY yang selama berjalannya program memiliki atensi dan keaktifan yang cukup baik. Hal ini dapat disebabkan oleh adanya faktor seperti jeda pelatihan (pelatihan diadakan hari Senin dan Rabu, sehingga tidak ada hari Selasa), materi yang padat dan banyak, atau proses atensi yang belum optimal dari partisipan atau dari materi dan fasilitator berikan.

Hasil pretest dan posttest pada keterampilan komunikasi menunjukkan adanya peningkatan yang besar atau signifikan. Rata-rata gainscore yang diperoleh sebesar 24,125, dengan rata-rata pretest 33 dan rata-rata post-test mencapai 57,125. 33 menjadi 57,13. Hasil Wilcoxon Sign-rank Test variabel keterampilan komunikasi menunjukkan nilai $\mathrm{Z}=-2,524$ dan $p$-value $=0,012(>0,05)$ yang juga menunjukkan adanya peningkatan yang besar atau signifikan dalam keterampilan komunikasi. Selain karena pemberian materi, partisipan dari awal memang menunjukkan antusiasme yang besar pada proses bermain peran atau 
keterampilan komunikasi dibanding ketika hanya diberi materi saja secara searah. Pemberian materi secara lisan menurut mereka lebih efektif dan menyenangkan untuk dipraktikkan. Dalam contoh yang diperagakan oleh observer mengenai keterampilan komunikasi, partisipan memiliki atensi dan proses retensi yang baik. Dari hasil ini dapat dikatakan bahwa modul MISI mampu meningkatkan baik pengetahuan maupun keterampilan komunikasi orang tua mengenai materi kesehatan reproduksi dan seksual pada remaja.

Pada proses selanjutnya, yaitu evaluasi modul, baik oleh partisipan maupun observer, modul dinilai telah mampu mencapai tujuannya, serta memiliki materi yang mudah dipahami, media yang menarik, dan memadai, dan cukup dapat dipraktikkan di rumah.

Dari hasil di atas, pada proses pembentukan pengetahuan orang tua, hal ini telah sejalan dengan penelitian-penelitian terdahulu yang menunjukkan pentingnya pengetahuan orang tua terhadap kesehatan reproduksi dan seksual remaja. Orang tua di sini diberi bekal sebagai pendamping utama remaja untuk mengurangi perilaku seksual berisiko dan juga dampak di lapangan (Albertos et al., 2016; Mertia et al., 2011).

Proses belajar orang tua dalam modul MISI telah disesuaikan dengan Bandura (1988) mengenai pembelajaran observasional melalui materi pada sesi-sesi yang diberikan. Materi mengenai keterampilan komunikasi orang tua juga telah diberikan sesuai dengan strategi komunikasi efektif oleh McKay et al. (2009). Sedangkan perincian materi yang diberikan telah disesuaikan baik dengan penelitian terdahulu (Burrahma, 2018) yang berdasarkan panduan dari IPPF berupa edukasi mengenai pertumbuhan seksual dan reproduksi yang sehat, relasi interpersonal, komunikasi, citra diri remaja, pantangan berhubungan seksual (abstinence), pencegahan IMS dan kehamilan remaja, pencegahan kekerasan, hak-hak reproduksi, hingga melatih tanggung jawab remaja akan tubuhnya (Breuner \& Mattson, 2016; Haberland \& Rogow, 2014) yang kesemuanya telah tercantum dalam materi modul MISI.

Proses belajar orang tua untuk meningkatkan pengetahuan dan keterampilan ada di setiap sesi program MISI, yaitu pada proses atensi, retensi, reproduksi dan motivasi perilaku. Proses atensi maupun retensi yang diberikan orang tua atau partisipan dalam sesinya berada dalam kategori baik, meskipun menurut beberapa catatan observasi ada beberapa ketimpangan keaktifan partisipan. Selain itu, adanya beberapa materi yang diberikan dengan jalan searah juga dapat menyebabkan kelelahan pada partisipan, terutama karena pelatihan dilakukan pada sore hingga malam hari. Hal ini dapat menyebabkan kurangnya proses atensi dan retensi. Pemilihan waktu pelatihan yang berjarak satu hari juga dapat mempengaruhi hasil dari penyerapan pengetahuan orang tua, meski fasilitator telah merangkum ulang materi di hari sebelumnya. Materi yang padat dan banyak dan diberikan dalam hanya dua kali pertemuan dapat menyebabkan kelelahan pada partisipan.

Proses pemberian materi yang berupa video yang dilanjutkan dengan diskusi dua arah lebih menarik perhatian atau atensi peserta. Beberapa partisipan menjadi lebih memperhatikan dan tertarik pada materi yang diberikan, kemudian lebih ikut terlibat dalam diskusi materi. Hal ini sejalan dengan Allison et al., (2012) dan Deaton (2015) yang 
menunjukkan adanya pengaruh positif penggunaan video sebagai salah satu media materi psikoedukasi karena lebih interaktif, sesuai dengan informasi terbaru, menarik secara visual, serta mampu meningkatkan motivasi bagi yang melihatnya. Video juga dapat memberikan gambaran secara nyata contoh materi di lapangan.

Penggunaan materi video ini juga menyesuaikan dengan relevansi adanya tambahan materi mengenai perkembangan teknologi informasi dan dampaknya di lapangan. Dalam penyampaian materi tersebut, disebutkan pula bahwa internet juga memiliki dampak positif, di antaranya sebagai media pembelajaran. Materi ini juga telah menarik atensi dan retensi partisipan dengan baik, karena partisipan merasa memiliki keterkaitan erat dengan keseharian mereka yang memiliki anak bermain dengan gawai tanpa mengetahui risikonya. Hal ini sejalan dengan Levine (2011) mengenai perlunya edukasi terhadap orang tua agar relevan dalam perkembangan teknologi, sehingga dapat memberikan pendampingan yang lebih optimal terhadap anak mereka.

Proses reproduksi dalam modul ini berupa bermain peran yang dilakukan untuk melatih keterampilan komunikasi orang tua kepada anak mengenai materi kesehatan reproduksi dan seksual. Sesuai dengan Bandura (1988), partisipan diminta untuk melihat contoh atau model yang diperagakan oleh observer untuk kemudian dipraktikkan atau dilatihkan pada bermain peran. Dalam praktiknya, partisipan pada mulanya merasakan kesulitan dalam bermain peran yang sesuai dengan prinsip komunikasi efektif maupun materi kesehatan reproduksi dan seksual. Hal ini dapat dipahami karena sesuai dengan temuan-temuan terdahulu, orang tua mengalami hambatan dalam berkomunikasi dengan anak karena belum menerapkan strategi komunikasi efektif. Pada topik mengenai kesehatan reproduksi dan seksual, beberapa partisipan seperti LNH dan EWW menyatakan belum nyaman dengan topik tersebut pada awalnya, serta bingung menyampaikan materi dengan bahasa yang lebih sederhana meski sudah diberi contoh (Walker et al., 2008). Hal ini juga sesuai dengan temuan-temuan terdahulu mengenai adanya hambatan seperti rasa malu orang tua, berpikir bahwa ini adalah topik yang tabu, ketidakterbukaan orang tua terhadap anak dan sebaliknya, serta kurangnya kepercayaan diri orang tua mengenai pengetahuan mereka terhadap topik tersebut.

Meski demikian, dari hasil post test, terjadi peningkatan yang signifikan terhadap keterampilan komunikasi orang tua. Hal ini dapat disebabkan oleh antusiasme yang besar pada proses bermain peran serta modeling yang dicontohkan baik oleh fasilitator maupun observer ketika memberikan contoh. Selain itu, proses keterampilan komunikasi juga langsung dipraktikkan sehingga partisipan mengalami pengalaman baru yang tidak menjemukan seperti pemberian materi semata yang berjalan satu arah. Dengan demikian dapat dikatakan bahwa modul MISI mampu mencapai tujuannya dalam meningkatkan keterampilan komunikasi pada orang tua, sejalan dengan modul sebelumnya yaitu PIJAR oleh Burrahma (2018).

Pada proses motivasi, dari hasil evaluasi serta interaksi partisipan dapat diperoleh bahwa partisipan menunjukkan keinginan yang kuat untuk mempraktikkan keterampilan dan pengetahuan yang mereka dapat dari modul ini. Hal ini dilihat dari keaktifan beberapa 
partisipan untuk membagikan cerita mereka mengenai keadaan di lapangan maupun keluarga, serta pertanyaan dan diskusi mengenai kasus-kasus yang mereka temui setiap hari, terlebih mengingat kerawanan daerah tersebut. Hasil evaluasi juga menunjukkan bahwa materi modul MISI dianggap memadai, mudah dipahami, dan dapat dipraktikkan oleh partisipan di rumah. Buklet MISI sebagai media pembantu juga dibekalkan kepada partisipan di akhir pelatihan sebagai media belajar mereka untuk kemudian dipraktikkan di rumah. Hal ini sesuai dengan Paramastri et al. (2011) yang menyatakan bahwa penggunaan media buklet akan efektif jika sesuai dengan materi, tujuan, serta memiliki tampilan yang nyaman untuk dipelajari.

Dari hasil pembahasan di atas, dapat dikatakan bahwa modul MISI telah memenuhi tujuannya dan dapat menjadi salah satu psikoedukasi dalam bentuk pendekatan informasi dan pemberian keahlian (Srivastava \& Panday, 2016) mengenai keterampilan komunikasi dan pengetahuan kesehatan reproduksi remaja. Selain itu, modul MISI juga membawa pengembangan dari modul sebelumnya yaitu mengenai topik mengenai perkembangan teknologi yang dalam penerapannya sesuai dan relevan dengan kaitan pendidikan kesehatan reproduksi dan seksual. Selain itu, dalam pelaksanaan ujicobanya, modul MISI tidak mengalami adanya mortalitas partisipan, meskipun jarak antara pelatihan di hari pertama dan hari kedua memiliki jarak satu hari.

\section{Kesimpulan}

Modul MISI valid baik secara isi maupun empirik untuk meningkatkan pengetahuan dan keterampilan komunikasi orang tua untuk menyampaikan materi kesehatan reproduksi dan seksual pada remaja. Modul ini dapat digunakan sebagai acuan pendidikan kesehatan reproduksi dan seksual pada remaja yang dapat disampaikan oleh orang tua kepada anak mereka yang berusia 9-15 tahun.

\section{Saran}

Modul ini dapat dikembangkan lebih lanjut, baik dari segi materi dan teknis pelaksanaan. Sisi materi dapat disesuaikan dengan relevansi perkembangan dinamika komunikasi orang tua dan anak serta zaman dan pengetahuan, sedangkan pada teknis pelaksanaan dapat dipertimbangkan hal-hal yang sehubungan dengan waktu maupun penyampaian. Alokasi waktu dapat dipecah menjadi pertemuan yang lebih panjang, maupun teknis pelaksanaan dapat dilakukan pada waktu-waktu yang lebih leluasa dan tidak melelahkan bagi partisipan. Bagi partisipan penelitian, modul ini dapat diteruskan untuk menyampaikan pengetahuan dan keterampilan yang sudah didapat baik kepada anak mereka untuk mencegah terjadinya perilaku berisiko. Bagi lingkungan, komunitas, atau Puskesmas terkait, diharapkan adanya kepedulian yang lebih dan menerapkan program terkait kesehatan reproduksi dan seksual terutama pada kegiatan yang rawan. 


\section{Kepustakaan}

Albertos, A. Osorio, A. Burgo, C.L., Carlos, S., Beltramo, C., \& Trullols, F. (2016). Parental knowledge and adolescents' risk behaviors. Journal of Adolescence, 53, 231 - 236.

Allison, S., Bauermeister, J.A., Bull, S., Lightfoot, M. Mustanski, Shegog, R. , \& Levine, D. (2012). The intersection of youth, technology, and new media with sexual health: moving the research agenda forward. Journal of Adolescent Health, 5(3), 207-212. doi:10.1016/j.jadohealth.2012.06.012

APA. (2005). Resolution in favour of empirically supported sex education and HIV prevention programs for adolescents. American Psychological Association.

Azwar, S. (2014). Metode Penelitian Psikologi. Pustaka Pelajar.

Azwar, S. (2015). Reliabilitas dan Validitas. Pustaka Pelajar.

Bandura, A. (1988). Perceived self-efficacy: Exercise of control through self-belief. Dalam J. Dauwalder, M. Perrez, \& V. Hobi (Eds.), Annual series of European research in behavior therapy (Vol. 2, pp. 27-59). Swets \& Zeitlinger.

Bearinger, L.H., Sieving, R.E., Ferguson, J. \& Sharma, V. (2007). Global perspective on the sexual and reproductive health of adolescents: patterns, prevention, and potential. The Lancet, 369 (9658), 1220 - 1231. https://doi.org/10.1016/S1040-6736(07)60367-5.

Burrahma, M.Z. (2018). Pelatihan Pijar untuk meningkatkan keterampilan komunikasi ibu dalam menyampaikan materi kesehatan reproduksi dan seksual (Tesis master tidak dipublikasikan). Universitas Gadjah Mada.

Breuner. C. C. \& Mattson, G. (2016). Sexuality education for children and adolescents. Pediatrics, 138(2), e20161348. https://doi.org/10.1542/peds.2016-1348

Casey, B.J., Getz, S., Galvan, A. (2008). The adolescent brain. Developmental Review, 28(1), 62 77. http://doi.org/10.1016/j.dr.2007.08.003.

Corcoran, J. (2016). Teenage pregnancy and mental health. Societies, 6(21), 1 - 9. http://doi.org/10.3390/soc6030021

David-Ferdon, C. (2014). Preventing Youth Violence: Opportunities for Action-CDC. CDC.

Deaton, S. (2015). Social learning theory in the age of social media: implications for educational practitioners. Journal of Educational Technology, 12(1), 1-5.

Departemen Kesehatan Republik Indonesia (2013). Riset Kesehatan Dasar 2013. Badan Penelitian dan Pengembangan Kesehatan.

DeVito, J. A. (2014). The Interpersonal Communication Book 13th edition. Essex: Pearson Education Limited.

Dowdell, E.B., Burgess, A.W., \& Flores J.R. (2011). Online social networking patterns among adolescents, young adults, and sexual offenders. The American Journal of Nursing, 111(7), $28-36$.

Field, A. (2009). Discovering Statistics Using SPSS for Windows. Sage Publications.

Hapsari, P.R. (2018). Validasi modul Panda untuk meningkatkan self-efficacy dan keterampilan komunikasi kesehatan reproduksi (Tesis master tidak dipublikasikan). Universitas Gadjah Mada. 
Islawati, I. \& Paramastri, I. (2015). Program Jari Peri sebagai pelindung anak dari kekerasan seksual. Jurnal Psikologi, 42(2), 115-128.

Kaufman, M. (2008). Care of the adolescent sexual assault victim. Pediatrics, 122(8), $462-470$.

Kipping, R.R., Campbell, R.M., MacArthur, G.J., Gunnell, D.J., \& Hickman, M. (2012). Multiple risk behavior in adolescence. Journal of Public Health, 34(1), i1 - i2. http://doi.org/10.1093/pubmed/fdr122

Kirby, D. (2008). The impact of abstinence and comprehensive sex and STD/HIV education programs on adolescent sexual behavior. Sexuality Research and Social Policy, 5(3), 18 27. http://doi.org/10.1525/srsp.2008.5.3.18.

Kohler, P. K., Manhart, L. E., \& Lafferty, W. E. (2008). Abstinence-only and comprehensive sex education and the initiation of sexual activity and teen pregnancy [Abstract]. Journal of Adolescent Health, 42(4), 344-351. http://doi.org/10.1016/j.jadohealth.2007.08.026.

Levine, D. (2011). Using technology, new media, and mobile for sexual and reproductive health. Sexuality Research and Social Policy, 8, 18-26. DOI 10.1007/s13178-011-0040-7

Lezin, N., Rolleri, L. A., Bean, S., \& Taylor, J. (2004). Parent-child connectednes : Implications for research, interventions, and positive impacts on adolescent health. ETR Associates.

Lindberg, L. D., Maddow-Zimet, I., \& Boonstra, H. (2012). Consequences of sex education on teen and young adult sexual behaviors and outcomes. The Journal of Adolescent Health, 51, 332-338. http://doi.org/10.1016/j.jadohealth.2011.12.028.

McKay, M., Davis, M., \& Fanning, P. (2009). Messages: The communication skills book. New Harbinger Publication.

Mertia, E.N., Hidayat, T. Yuliadi, I. (2011). Hubungan antara pengetahuan seksualitas dan kualitas komunikasi orang tua dan anak dengan perilaku seks bebas pada remaja siswa-siswi MAN Gondangrejo Karanganyar. Jurnal Wacana Psikologi, 3(2), 1-28.

Moawad, G.E.L. \& Ebrahem, G.G.S. (2016). The relationship between use of technology and parent-adolescents social relationship. Journal of Education and Practice, 7 (14), 168 178.

Mueller, T.E., Gavin, L.E., \& Kulkarni, A. (2008). The association between sex education and youth's engagement in sexual intercourse, age at first intercourse, and birth control use at first sex. Journal of Adolescent Health,42 (1), 89 - 96.

Paramastri, I., Prawitasari, J. E., Prabandari, Y. S., \& Ekowarni, E. (2011). Buklet sebagai media pencegahan terhadap kekerasan seksual pada anak-anak. Jurnal Kesehatan Masyarakat Nasional, 6(2), 77-84.

Pop, M. V. \& Rusu, A. S. (2015). The role of parents in shaping and improving the sexual health of children - lines of developing parental sexuality education programmes. Procedia - Social and Behavioral Sciences, 209(July), 395-401.

Romero, T., Otgaar, H., \& Landstrom, S. (2018). Coping with sexual abuse. Psychological Research on Urban Society, 1(1), $46-54$.

Rosyidah, F.N. \& Nurdin, M.F. (2018). Media sosial sebagai ruang baru dalam tindak pelecehan seksual remaja. Sosioglobal, 2(2), $38-48$. 
Santrock, J.W. (2007). Remaja. Erlangga.

Solenta, V.A. (2019). Program "Kenari Duri" untuk meningkatkan pengetahuan Guru SLB tentang pencegahan kekerasan seksual bagi anak tunagrahita (Tesis master tidak dipublikasikan). Universitas Gadjah Mada.

Srivastava, P. \& Panday, R. (2016). Psychoeducation an effective tool as treatment modality in mental health. The International Journal of Indian Psychology, 4(1), 123 - 130.

Vreeman, R.C., McCoy, B.M., \& Lee, S. (2017). Mental health challenges among adolescents living with HIV. Journal of the International AIDS Society, 20(3), 25 - 31. http://doi.org/10.7448/IAS.20.4.21497

Walker, L.R., Rose, A., Squire, C., Koo, H.P. (2008). Parents' views on sexual debut among pre-teen children in Washington, DC. Sex Education, 8(2), 169 - 185.

Wooden, C. L., \& Anderson, F. R., (2012). Engaging parents in reproductive health education: lessons learned implementing a parent designed,peer-led educational model for parents of preteens. American Journal of Sexuality Education, 7(4), 461-473.

WHO. (2018). Adolescent Pregnancy. https://www.who.int/news-room/factsheets/detail/adolescent-pregnancy, diakses 23 Maret 2019.

Yullidya, N. (2015). Pelatihan kesehatan reproduksi untuk meningkatkan komunikasi efektif orang tua kepada anak. Jurnal Psikologi Tabularasa, 10(2), 215 - 235. 